\title{
Research of innovations implementation within the seaport anti-crisis policy
}

\author{
Elena Korchagina ${ }^{1, *}$, Elena Naumova $^{2}$, Kristina Kryukova ${ }^{1}$, and Vladimir Bakharev ${ }^{1}$ \\ ${ }^{1}$ Peter the Great St. Petersburg Polytechnic University, Polytechnicheskaya, 29, St. Petersburg, \\ 195251, Russia \\ ${ }^{2}$ Saint Petersburg State Maritime Technical University, Saint-Petersburg, Lotsmanskaya str., 10, St. \\ Petersburg, 190121, Russia
}

\begin{abstract}
The scientific task of the research consists in solving the difficult contradiction between the need to decrease the expenses according to the ant-crisis policy on one hand and the necessity to implement innovations for increasing efficiency of supply chain on the other hand. The features of modelling of the process of innovations implementations are studied regarding the seaport as an important element I supply chain infrastructure. Seaports are the main links of the global transport infrastructure. They make it possible to have trade partnership between countries. Here the process of innovation implementation on the example of anti-crisis measures for the ports as institutional and operational clusters is presented. Theoretical framework to conceptualize innovations at a commercial seaport as anti-crisis complex process. The primary objective for the commercial seaport is marine terminals' modernization through rational distribution of cargo flows and reconstruction of capacities for certain types of cargo. New tools and technologies as well as modern intelligent control systems of industrial and economic processes can add up to the innovative component in the development of the commercial seaport. Active implementation of logistics transport and technological systems is proven to be the most effective route in the field of innovative development.
\end{abstract}

\section{Introduction}

The nature and extent of the scientific task covers the features of modelling of the process of innovations implementations regarding the anti-crisis policy of companies involved in supply chains. The research is dedicated to providing the results that combine scrupulous academic study and the implementation of original approach to seaport infrastructure innovations on the basis of logistic principles. Throughout the world, port activities are one of the key areas of development of the country's economy. Seaports play a very important role for the economy of the region due to its island geographical position. They are the main transport arteries through which a major part of cargo goes arriving to and departing from the island. Ports are the main links of the entire global transport infrastructure that provide access to the trade partnership between the countries. A

\footnotetext{
${ }^{*}$ Corresponding author: elena.korchagina@mail.ru
} 
modern seaport is a technically equipped enterprise, which has sea and land territories serving for loading and unloading operations, boarding and unloading of passengers. It also serves to monitor compliance with commercial shipping international agreements. The main task of the paper is the investigation of the process of the seaport infrastructure innovations implementation as the parcel part of complex anti-crisis policy.

Prominent scientists have performed multiple researches on development of ports, their roles and function in supply chains, economies and transport infrastructure systems [1-5], which typically consider various theoretical approaches to the development of transport infrastructure. Key performance indicators for developing environmentally sustainable marine ports are reviewed by [6]. We agree with K.Y. Bjerkan and H. Seter [7] studying the green ports and maritime logistics that there are insufficient data provided in literature sources for good decision making in ports. The investment projects issues including IT and energy-saving technological infrastructure are studied by several authors [8-10]. In our opinion, undoubtedly, a few papers are based on empirical findings. Taking into account the importance of economic facts it is obvious to make our search on the basis of empirical data and port engagement. The suggested approach considers the decision making process in sea ports innovations especially in critical financial standing.

\section{Materials and Methods}

The method being used for the purpose of the research include the procedure of developing economic models and business process planning and optimizing. Description of the study location regards the anti-crisis measures taken for the seaports of the most actively developing regions of the Russian Federation. Addressing the seaport problems to the extent such information is relevant to the study, equipment modernization in the first instance, requires time and considerable investments lacking today. Therefore, the only possible way out of the situation is a phased implementation of the program of improvement of the enterprise activity, aimed at implementation of innovative solutions, raising the necessary investments and using government support.

The main task is to plan all logistics activities of the seaport's terminals, coordinate them with the work of the port's divisions (dispatcher department, accounting department, planning and economic department, automation department and etc.).

Assumptions made and their rationale regards the measures aiming to increase the efficiency of the seaport as far as the following actions could be considered as necessary:

1. operational works scheduling using up-to-date information on the current situation at the container terminal;

2. cutting time for shipping paperwork;

3. minimizing manual operations (preparation of loading plans, issuance of assignments to radio terminals and electronic boards) while scheduling works;

4. optimizing loading equipment's operation through interactive mode when issuing orders and obtaining accurate information about the location of the loaders; optimizing the way the containers are placed and minimizing empty movements of container trucks;

5. cutting the downtime of motorcars, ships and trains by planning personnel and loading equipment operations based on the information about the current location of containers;

6. cutting the time of filing primary accounting documentation, calculation of the cost of port services, payroll management and making financial statements.

Considering the methods of the research it should be taken into the account that commercial seaport requires full modernization and implementation of innovations, including in the management system. For example, coal loading and unloading works are 
carried out with loading bridges, loaders and workers who use shovels to throw coal into the buckets. While the works are carried out, a huge amount of coal dust goes into the air, and then spreads throughout the city by permanent winds. These works can continue from several days up to several weeks. It is obvious that in this case, it is pointless to discuss issues of productivity or compliance with labor and environmental standards.

During the research the data being analyzed and summarized regards the process of innovation implementation of anti-crisis measures taken for the seaports of the Sakhalin region, one of the most actively developing regions of the Russian Federation.

Nowadays the company "Kholmsky Commercial Seaport" PJSC experiences a crisis situation contributing to anti-crisis measures, including logistics innovations. Over the last three years there has been a steady increase in losses, leading to the fact that the mandatory requirement for the net assets to exceed the amount of the authorized capital of the company is violated and the negative trend continues to grow (Table 1).

Table 1. Net assets, authorized capital and profits (losses) of the enterprise (calculated on the basis of accounting financial statements [13])

\begin{tabular}{|l|c|c|c|}
\hline \multirow{2}{*}{ Indicator (thousand rubles) } & \multicolumn{3}{|c|}{ Period } \\
\cline { 2 - 4 } & 2016 & 2017 & 2018 \\
\hline 1. Gross loss & $-7,754$ & $-9,692$ & $-1,428$ \\
\hline 2. Loss on sales & $-46,014$ & $-44,967$ & 27,780 \\
\hline 3. Net loss & $-94,404$ & $-47,613$ & $-62,601$ \\
\hline 4. Net assets & $-26,018$ & $-73,631$ & $-168,035$ \\
\hline 5. Authorized capital & 86,586 & 86,586 & 86,586 \\
\hline $\begin{array}{l}\text { 6. Excess of net assets over } \\
\text { authorized capital (line 4 - line 5) }\end{array}$ & $-112,604$ & $-160,217$ & $-254,622$ \\
\hline
\end{tabular}

The existing production capacity of the "Kholmsky Commercial Seaport" PJSC has long been outdated. According to the reports [11], wearing of equipment is more than 60 percent. Additionally to this fact, in 2017 and 2018 there was no equipment renovation of any kind. The most part of loading bridges engaged in loading and unloading operations was installed in the seaport in the early 1970s. And even the equipment that seemed quite modern a decade ago, does not only fail to meet global needs today, but stacks up badly with the equipment installed in most large and medium ports of the Russian Federation.

Until recently, the main transportation hub of the Sakhalin region was the Kholmsky commercial seaport - the only port on the island, which includes two harbors - South and North harbors. The South harbor is specially equipped for handling the railroad ferry ships on the route "Vanino - Kholmsk" as well as vessels with various cargoes like coal, wood and containers. The North harbor specializes in handling vessels and facilitating offshore drilling platforms.

The North harbor's operator is the Joint Venture Limited Liability Company "Sakhalin-Shelf-Service". The company's fleet consists mainly of vessels facilitating drilling rigs and icebreakers. The company works hand in hand with "Gazprom Fleet" LLC and provides it a coastal supply base for marine exploration in the Kirinsky block on the Sakhalin shelf within the framework of the "Sakhalin-3" project. "Sakhalin 3" is an oil and gas project on the coast of the Sakhalin Island, comprising of four blocks of fields (Kirinsky, Veninsky, Ayashsky and Vostochno-Odoptinsky blocks) on the shelf of the Sea of Okhotsk.

The operator of the South harbor is "Kholmsky Commercial Seaport" PJSC, shares of which in early 2018 were bought by "Petrosakh" CJSC due to the bankruptcy of the first company. "Petrosakh" Company was founded in 1991 to develop the Okruzhnoye oil field at the Smirnykhovsky district of the Sakhalin Island. The company became one of the first joint ventures in the Far East region with the founders including the Sakhalin multi-industry company "Sameco" and "Smith Energy" Company, Texas, United States. 
The seaport owns marine terminals, railway deadlocks and vast unused territories where, for example, fuel and lubricants storage facilities can be built.

The program for the Kholmsky commercial seaport should be developed in accordance with the adopted Seaports Infrastructure Development Strategy in Russia until 2030 [11], the purpose of which is to create an innovative infrastructure in seaports and integrate them into transport nodes, where the state takes a stimulating role under ports comprehensive development [11]. The program's development and adoption are also necessary because the absence of a unified and coordinated plan of action of the founders of the enterprise seems to be the main reason hindering the development of the main sea harbor of the Sakhalin Island.

\section{Results}

The results of the research could be clearly represented as the approach for developing scenario of consequent business procedures including innovations on one hand as well as anti-crisis measures on the other to solve the contradiction between the increase of expenses and the necessity to implement the innovations. The following scenario for the principal innovative development of commercial seaport, consisting of several interrelated stages can be suggested:

1. The study of the ways for renewal of stable operation of the enterprise and implementation of a number of measures allowing the enterprise to get out of crisis, namely:

- to analyze the current financial situation, identifying and structuring existing debts, claims of creditors, etc;

- to consider the possibility of assigning rights to a bank or factoring company to claim part of receivables;

- to consider the possibility of updating the material and technical resources of the seaport by means of leasing operations, which does not require full singletime payment of the property;

- to borrow contract loans for profitable projects that can bring high income to the enterprise;

- to reduce or completely waive dividend payments on shares, provided that shareholders can be convinced of the viability of the financial recovery program and the increase in dividend payments in the future;

- to reduce costs and improve seaport's efficiency by eliminating unprofitable activities.

2. Seaport capacity improvement and efficient development of the seaport's infrastructure.

3. Ensure safe operation of the seaport infrastructure and maritime transport.

To improve the overall safety of the seaport's transport system the following steps are necessary:

- to constantly carry out nautical survey and optimize vessel traffic routes, to ensure the operation of vessel reporting systems;

- to train qualified personnel in maritime transport operations in accordance with international standards;

- to develop and implement an efficient system of measures to protect transport infrastructure facilities and vehicles in seaports from potential, immediate and direct threats of acts of illegal interference with maritime transport activity; 
- to start implementing advanced technologies, specialized equipment and innovative engineering and technical means to identify and prevent safety threats to transport infrastructure's facilities and vehicles;

- to improve methods of using funds received from collecting the environmental fee, and channeling the latter for the maintenance and improvement of technical means for receiving and processing shipboard wastes.

All these measures will improve the safety of navigation on sea routes, approach channels and in the seaport's waters, reduce the number of accidents and minimize their consequences [12].

4. Creating conditions improving competitive performance of Commercial Seaport.

For instance, the primary objective for the Kholmsky commercial seaport is marine terminals' modernization through rational distribution of cargo flows and reconstruction of capacities for certain types of cargo. The existing about five meters depths in the Kholmsky seaport make it impossible to take large vessels. The bottom is planned to be deepened up to 9.5 meters in 2019-2021. Berths reconstruction project has already passed ecological examination. Bottom deepening works for the main marine harbor of the island have not been carried out for almost 20 years. Currently, the seaport only works with halfloaded vessels, and this situation is extremely unprofitable for ship owners [16]. New tools and technologies can add up to the innovative component in the development of the Kholmsky commercial seaport as well as modern intelligent control systems of industrial and economic processes. Active implementation of logistics transport and technological systems is proven to be the most effective route in the field of innovative development.

In order to improve the competitive performance of the commercial seaport and, mainly, the safety of navigation, it is necessary to start the construction, renovation and renewal of the auxiliary fleet, bringing the average age of vessels to not older than 15 years. For example, the three currently active ferries shipping bulk cargo in tanks, perishable goods in refrigerated cars, refrigerated compartments and temperature control cars, dangerous goods, passenger cars, trucks as well as transporting passengers, were built in 1985, 1986 and 1992, respectively [13].

The seaport's infrastructure development creates attractive conditions for vessels entering the seaport. Maintenance of port fees and tariffs for loading and unloading works that can be rendered in a seaport, contributes to an increase in the number of entries to the port [14].

The improvement of tariff and price regulation for services rendered in a seaport should be based on the following principles:

- $\quad$ state regulation of prices should apply only to services provided in the field of activity of the natural monopolies holders;

- a full transition from the "cost-plus" model (full recovery of all reasonable costs incurred plus profitability) to the long-term price limit model;

- separate accounting of income and expenses by types of activity of regulation entities;

- gradual elimination of managing loading and unloading tariffs due to competition development in the markets, as well as elimination of managing tariffs for berthing and cargo storage services in seaports.

5. Improvement of public administration in maritime port economy.

Implementation of the planned goals, as well as of all of the above tasks, is not possible without improvement of state administration in maritime port economy.

First of all, the role of the region's government is obvious in the issue of stimulating and attracting private investments into the seaport infrastructure. Lack of the government support will make it impossible to increase efficiency of the seaport in the near future. Public authorities must participate in the issues of making the city-forming enterprise of 
this kind an investment and economic attractive one. Government support is necessary in the following matters [15]:

- to encourage private investment attraction to the seaport's infrastructure;

- to improve the accessibility of services for passengers and tourists, including disabled people and people with special needs;

- to improve the level of professional training for seaport personnel;

- to organize a modern multilevel and multifunctional automated system managing the operation and development of commercial seaport;

- to further improve the system of managing the seaport assets in the region as well as the system of regulatory and legal support of the seaport's activities.

6. Formalization and automation of the seaport's business processes.

\section{Discussion}

Considering the meanings and implications of the achieved results one can prove that creation of an efficient seaport's management system is possible on the basis of an adequate comprehensive automated information system.

The main reasons for downtime due to the works organized in such a manner are the following:

- the lack of efficient management of container movements within the port;

- a large portion of operations performed manually at the dispatcher and accounting departments;

- inefficient use of loading equipment.

The desire to increase cargo turnover and production capacity poses new challenges before the seaport's management; now it needs to improve efficiency, formalization and automation of the main business processes.

Formalization and automation will make it possible to optimize interaction of all port structures between each other in order to achieve high quality of rendered services.

The easiest way to formalization is to write down the business processes of the enterprise as well as regulations for each employee. However, pure formalization of business processes (only "on paper") does not make it possible to control compliance with the established regulations in practice.

Formalization of business processes through the introduction of automated systems can be suggested, which will help to achieve the following goals:

1. creation of a unified information environment and a regulatory reference database;

2. making business processes more coherent;

3. elimination of the downtime for data communication between departments;

4. flexible tariff plans application and development.

The system's implementation will halve the time required for data entry and increase calculations and making documents by a factor of 5 to 6 .

\section{Conclusion}

The innovative development measures of the Commercial Seaport will allow to achieve the following goals:

- improved comprehensive safety of navigation in the seaport area by optimizing vessel routes and ship reporting systems, introducing advanced technologies and innovative technical means of detection and prevention of safety threats to transport infrastructure; 
- improved attractiveness of the seaport to ship owners through revising the port's charges;

- improved innovative component of the seaport's activity through the use of information technologies; resource saving measures implementation, cutting the negative impact on the environment, and strengthening sectoral human resources capacity;

- improvement of public administration in managing the seaport assets, application of new institutional arrangements (e.g. creation of port's special economic zones);

- development of infrastructure for handling heavy-tonnage vessels, which will improve the seaport's attractiveness in terms of reducing transaction costs.

\section{References}

1. M. Acciaro, H. Chiara, M.I. Cusano, Energy Policy 71, 4-12 (2014). https://doi.org/10.1016/j.enpol.2014.04.013

2. M. Acciaro, C. Ferrari, J.S.L. Lam, R. Macario, A. Roumboutsos, C. Sys, A. Tei, T. Vanelslander, Maritime Policy Manage 456, 787-802 (2018). https://doi.org/10.1080/03088839.2018.1466062.

3. Michele Acciaro, Thierry Vanelslander, Christa Sys, Claudio Ferrari, Athena Roumboutsos, Genevieve Giuliano, Jasmine Lam, Lee Siu, Seraphim Kapros, Maritime Policy Manage. 41(5), 480-500 (2014) https://doi.org/10.1080/03088839.2014.932926.

4. R.Bergqvist, C. Macharis, D. Meers, J. Woxenius,. Res. Transp. Bus. Manage. 14, 80-89 (2015). https://doi.org/10.1016/j.rtbm.2014.10.009.

5. S. Cheon, Sustain. Develop. 25, 50-62 (2017). https://doi.org/10.1002/sd.1641

6. A. Di Vaio, L. Varriale, F. Alvino, Energy Policy 122, 229-240 (2018). https://doi.org/10.1016/j.enpol.2018.07.046.

7. K. Y. Bjerkan, H Seter, Transportation Research Part D: Transport and Environment 72, 243-260 (2019). https://doi.org/10.1016/j.trd.2019.05.003

8. N. Solonina, L. Alekseeva, S. Barykin, MATEC Web of Conferences 265, 07021 (2019). https://doi.org/10.1051/matecconf/201926507021

9. E. Schislyaeva, O. Saychenko, S. Barykin, I. Kapustina, International Scientific Conference Energy Management of Municipal Facilities and Sustainable Energy Technologies EMMFT 2018. EMMFT-2018 Advances in Intelligent Systems and Computing, 983 (2019). https://doi.org/10.1007/978-3-030-19868-8_32

10. O. Kalinina, S. Firova, S. Barykin, I. Kapustina, International Scientific Conference Energy Management of Municipal Facilities and Sustainable Energy Technologies EMMFT 2018. EMMFT-2018 2018. Advances in Intelligent Systems and Computing, 982. (to be published). https://doi.org/10.1007/978-3-030-19756-8_29

11. Laws and regulations / Seaports Infrastructure Development Strategy in Russia until 2030. Creation of innovative infrastructure of seaports - electronic portal. 2012: https://bazanpa.ru/pravitelstvo-rf-strategiia-ot28092012-h2949632/4/4.4

12. Maritime News of Russia/Kholmsk City Port: time of change - electronic portal. 2014: http://www.morvesti.ru/analitics/detail.php?ID=31271

13. Seaports / Federal Agency of Sea and River Transport of the Russian Federation: http://old.morflot.ru/deyatelnost/napravleniya_deyatelnosti/portyi_rf.html 
14. Maritime News of Russia/Kholmsk City Port: winter navigation, operation and the future of ferry service. 2018: http://www.morvesti.ru/analitics/detail.php?ID=72049

15. N.Yu. Bodrovtseva, State and municipal management in the 21st century: theory, methodology, practice 27, 6-19 (2017)

16. SKRIN (Information disclosure web-site).

https://disclosure.skrin.ru/disclosure/6509001181/?DTI=8 